\title{
ACTH Release in Pituitary Cell Cultures. Effect of Neurogenic Peptides and Neurotransmitter Substances on ACTH Release induced by Hypothalamic Corticotropin Releasing Factor (CRF)
}

\author{
Kozo HASHIMOTO, SHo YUNOKI, JiRo TAKAHARA \\ AND TADASHI OFUJI \\ Third Department of Internal Medicine, Okayama University \\ Medical School, Okayama-shi 700, Japan
}

\begin{abstract}
Synopsis
The effects of various neurogenic peptides and neurotransmitter substances on the release of ACTH induced by hypothalamic corticotropin releasing factor (HYCRF) were investigated using monolayer cultured anterior pituitary cells. Test substances were given in combination with $0.05-0.1$ hypothalamic extract $(\mathrm{HE}) / \mathrm{ml}$, because HE evoked a significant ACTH release and a linear dose response relationship was demonstrated sequentially between $0.0165 \mathrm{HE} / \mathrm{ml}$ and $0.5 \mathrm{HE} / \mathrm{ml}$. Relatively high doses of lysine-vasopressin showed a slight additive effect on the release of ACTH induced by $0.1 \mathrm{HE} / \mathrm{m} l$. Leu-enkephalin, dopamine, prostaglandin $\mathrm{E}_{1}$ and $\mathrm{E}_{2}$ slightly reduced the release of ACTH induced by HY-CRF, but the inhibitory effect of these substances were not dose-related. Other tested substances including luteinizing hormone releasing hormone, thyrottopin releasing hormone, somatostatin, melanocyte stimulating hormone release inhibiting factor, $\beta$-endorphin, neurotensin, substance $\mathbf{P}$, vasoactive intestinal polypeptide, angiotensin II, norepinephrine, serotonin, acetylcholine, histamine and $\gamma$-amino butyric acid showed neither agonistic nor antagonistic effect on the release of ACTH induced by HY-CRF. These results indicate that the release of ACTH is controlled specifically by HY-CRF and corticosterone, and modified slightly by some other substances such as vasopressin and prostaglandins, and that the effect of most other neurogenic peptides and neurotransmitter substances is negligible or non-physiological at the pituitary level.
\end{abstract}

It has been well known that the hypothalamic corticotropin releasing factor (HY-CRF) controls the pituitary ACTH secretion. However, as pure CRF is not available, there still remain uncertain aspects in the hypothalamic controls of ACTH secretion. Recently it has been revealed that many kinds of biologically active peptides exist in the hypothalamus, and there is a possibility that these peptides or neurotransmitter substances have some effects on the release of ACTH from the pituitary. The good sensitivity and spe-

Received June 3, 1978. cificity of monolayer cultured anterior pituitary cells for detecting $\mathrm{CRE}(\mathrm{s})$ enabled us to show that most of these peptides and neurotransmitter substances do not have a CRF-like activity except for a few substances (Hashimoto et al., 1978) However, the possibility still remained that these substances might have an effect on HY-CRF induced release of ACTH from pituitary cells, and few reports are available on this point except for the effect of vasopressin (Yates et al., 1971; Portanova and Sayers, 1973; Yasuda and Greer, 1976). In the present investigation, the effects of various nəurogenic peptides and neurotransmitter 
substances on HY-CRF induced release of ACTH were examined in pituitary cell cultures.

\section{Materials and Methods}

\section{Preparations of cultured pituitary cells}

Charles River SD strain male rats, weighing 200 $350 \mathrm{~g}$, were decapitated. The anterior pituitaries were immediately removed, minced into small pieces and placed in Hank's-HEPES buffer. The pituitaries were then dispersed with enzyme using the procedure reported by Vale et al. (1972) with the modifications. The pituitaries were shaken at $37^{\circ} \mathrm{C}$ for $45 \mathrm{~min}$ with $10 \mathrm{~m} l$ Hank's-HEPES buffer containing $0.35 \%$ collagenase (GIBCO) and 1\% bovine serum albumin (BSA). They were then dispersed with $10 \mathrm{ml}$ Hank'sHEPES buffer containing $0.25 \%$ pancreatin and $1 \%$ BSA for $10 \mathrm{~min}$. Dispersed pituitary cells were washed 5 times with $3 \mathrm{ml}$ of sterile Dulbecco modified Eagle's medium (DMFM ; GIBCO) containing 10\% horse serum, $2.5 \%$ fetal calf serum, $1 \%$ non-essential amino acid (GIBCO), fungisone $2.5 \mu \mathrm{g} / \mathrm{ml}$, penicillin $50 \mathrm{U} / \mathrm{m} l$ and streptomycin $50 \mu \mathrm{g} / \mathrm{ml}$. The dispersed cells were resuspended in an appropriate volume of medium and were placed in sterile plastic Petri dishes (Falcon, $35 \times 10 \mathrm{~mm}$ ) containing serum-supplemented DMEM. Usually $2-5 \times 10^{5}$ cells per $1.5 \mathrm{~m} l$ medium were placed into a single dish, and three dishes were usually cultured from one pituitary. The dishes were cultured at $37^{\circ} \mathrm{C}$ for 4 days in an incubator with $95 \%$ air and $5 \% \mathrm{CO}_{2}$ and continuously supplied with water vapor.

\section{Experiments using cultured cells}

After 4 days of culture, cells were washed twice with fresh DMEM and then DMEM containing the test substances was added for incubation. Rat hypothalamic extract (HE) was obtained from NIH (NIAMD-Rat-HE-RP-1). The HE was dissolved in $0.01 \mathrm{~N}-\mathrm{HCl}$, divided into small aliquots $(5 \mathrm{HE} /$ $100 \mu l$ ) and frozen until used. Corticosterone (Sigma) was first dissolved in ethanol and further diluted with DMEM just before use. Other test substances and their sources were: luteinizing hormone-releasing hormone (LH-RH), thyrotropin releasing hormone (TRH), and $\gamma$-amino butyric acid (GABA) (Daiichi Pharmaceutical Co.); melanocyte stimulating hormone release inhibiting factor (MSH-IF), substance $\mathbf{P}$, neurotensin, $\beta$-endorphin and leu-enkephalin (Protein Research Foundation in Osaka); norepinephrine, serotonin, acetylcholine and histamine (Wako Pure Chemical Industries, LTD.); prostaglandin $\mathrm{F}_{1}\left(\mathrm{PGE}_{1}\right)$ and $\mathrm{PGE}_{2}$ (Ono Pharmaceutical Co.); dopamine (Nakarai Chemicals, LTD.); lysine vasopressin (LVP) (Sandoz Pharmaceutical Co.) and angiotensin II
(CIBA, LTD.). Somatostatin and vasoactive intestinal polypeptide (VIP) were gifts from Prof. N. Yanaihara (Shizuoka Pharmaceutical College). All test substances were dissolved and diluted with DMEM just before use. Most substances which showed no CRF-like activity in our former examination were added to incubation medium not alone but in combination with HE. Trasylol (1,000 U/dish) was added to all dishes. Test incubation was carried out in a volume of $2.0 \mathrm{ml} / \mathrm{dish}$ for $4 \mathrm{hrs}$. Three or four dishes were employed in each test group. In each assay, DMEM containing each dose of the test substance or HE was incubated in a dish without cells to check the amount of ACTH present in the HE. ACTH contamination was only detected slightly in dishes containing HE, was subtracted from the total ACTH detected to determine the net quantity of ACTH released.

\section{ACTH radioimmunoassay}

The amount of ACTH in the culture medium was assayed by a sensitive radioimmunoassay employing an anti-porcine $\mathrm{ACTH}$ serum which reacted with ACTH but did not cross react significantly with 'other pituitary hormones (Hashimoto et al., 1976) and test substances employed in the present investigation. Statistical analysis was conducted by Duncan's multiple range test.

\section{Result}

\section{Effect of HY-CRF and corticosterone on} ACTH release

Fig. 1 shows the dose-response effect of HY-CRF on ACTH release from pituitary cells in culture. The lowest detectable dose of hypothalamic extract $(\mathrm{HE})$ producing an ACTH response was usually $0.01 \mathrm{HE} /$ dish $(0.005 \mathrm{HE} / \mathrm{m} l)$, and a linear dose-response relationship was demonstrated sequentially between $0.0165 \mathrm{HE} / \mathrm{m} l$ and $0.5 \mathrm{HE} / \mathrm{m} l$. Therefore, 0.05 or $0.1 \mathrm{HE} / \mathrm{m} l$ was added to incubation medium in combination with test substance in the following experiments. Corticosterone at 1,10 and $100 \mathrm{ng} / \mathrm{m} l$ suppressed the basal ACTH secretion. But the suppression was not complete even by $100 \mathrm{ng} / \mathrm{m} l$ corticosterone. It also suppressed significantly the HY-CRF induced release of ACTH (Fig. 2). 


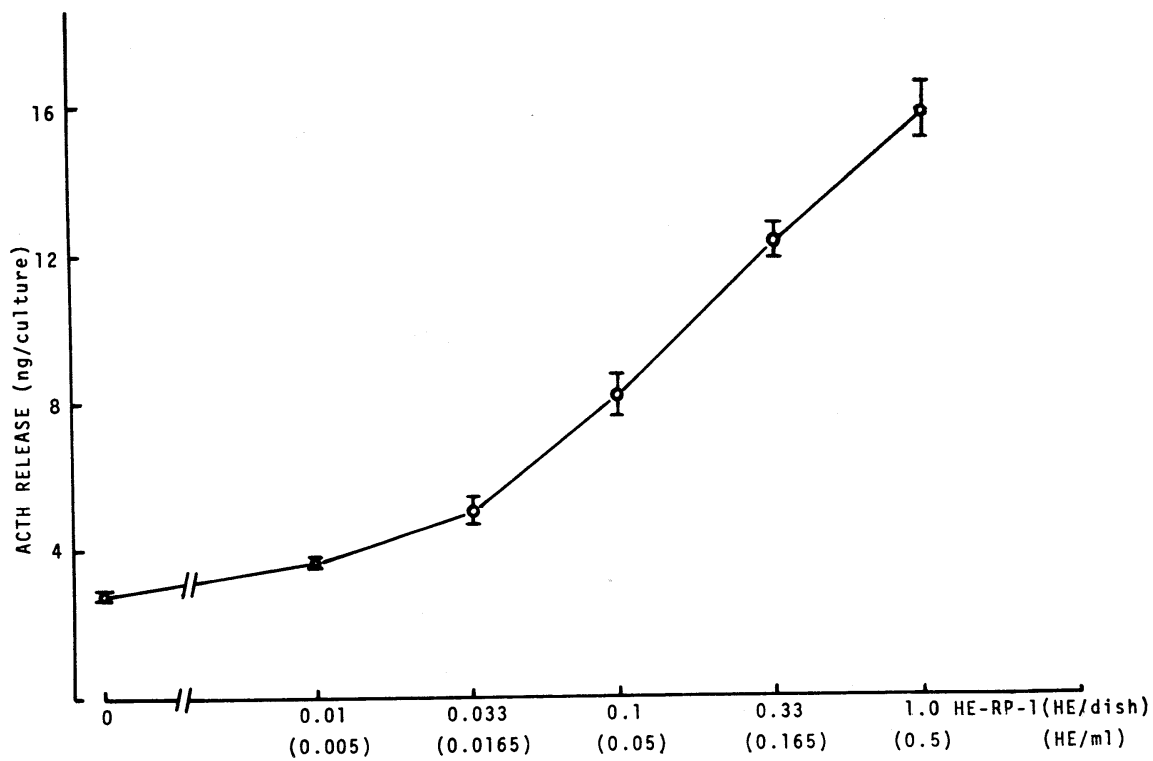

Fig. 1. Effect of hypothalamic extract (HE; NIAMD-Rat-HE-RP-1) on the release of ACTH in pituitary cell cultures. Three or four dishes were employed in each group. Histogram and bar represent the mean \pm SEM. All tested concentration of $\mathrm{HE}(0.01-1.0 \mathrm{HE} / \mathrm{dish})$ evoked a significant increase of ACTH.

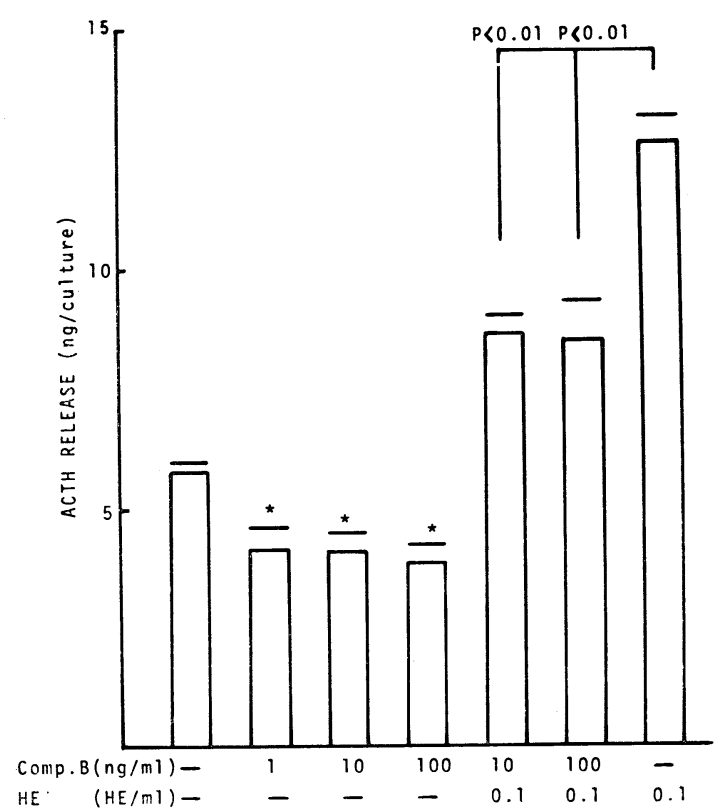

Fig. 2. Effect of corticosterone (Comp. B) on the basal and $0.1 \mathrm{HE} / \mathrm{m} l$ induced release of ACTH in pituitary cell cultures. It significantly suppressed both the basal $(* \mathbf{P}<0.05)$ and $\mathrm{HE}$-induced release of ACTH.

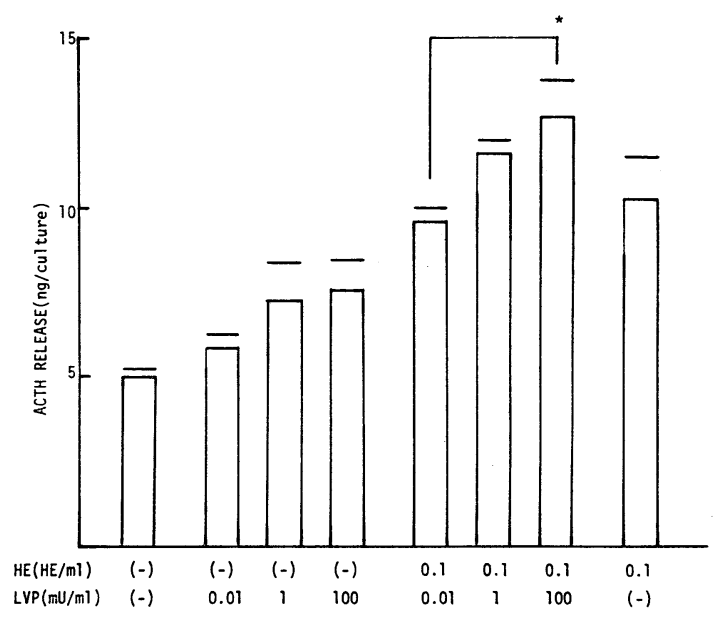

Fig. 3. Effect of LVP on the basal and $0.1 \mathrm{HE} / \mathrm{m} l$ induced-release of ACTH in pituitary cell cultures. More ACTH was released by $100 \mathrm{ng} / \mathrm{ml} \mathrm{LVP}$ than by $0.01 \mathrm{ng} / \mathrm{m} l \mathrm{LVP}$ when given in combination with $0.1 \mathrm{HE} / \mathrm{ml}(* \mathrm{p}<0.05)$. 
Effect of neurogenic peptides on HY-CRF induced ACTH release

LVP at a concentration of $10 \mu \mathrm{U} / \mathrm{m} l$ did not stimulate $\mathrm{ACTH}$ release but 1 and $100 \mathrm{mU} / \mathrm{m} l$ of the peptide evoked ACTH release in pituitary cell cultures as shown in our previous report (Fig. 3). When LVP was added in combination with HE, LVP at 1 and $100 \mathrm{mU} / \mathrm{m} l$ showed as light additive effect on HY-CRF induced ACTH release. Leu-enkephalin at 1,10 and $100 \mathrm{ng} / \mathrm{m} l$ showed slight inhibitory effect on the $0.05 \mathrm{HE} / \mathrm{ml}$ induced release of ACTH (Table 1). However, other neurogenic peptides including TRH, GIF, LH-RH, $\beta$-endrophin, MSH-IF; neurotensin, substance $P$ and angiotensin II showed neither stimulatory nor inhibitory effect on the HY-CRF induced release of ACTH in pituitary cell cultures. VIP at $0.1,1,10$ and $100 \mathrm{ng} / \mathrm{m} l$ showed neither stimulatory nor inhibitory effect on the basal and HY-CRF-induced release of ACTH (Fig. 4).

Effect of neurotransmitter substances on $H Y-C R F$ induced ACTH release

Norepinephrine, serotonin, acetylcholine and histamine at 1,10 and $100 \mathrm{ng} / \mathrm{m} l$ did not a show statistically significant effect on the HY-CRF-induced release of ACTH in pituitary cell cultures (Table 2). Dcpamine at $10 \mathrm{ng} / \mathrm{m} l$ reduced the $\mathrm{HY}-\mathrm{CRF}$-induced release of $\mathrm{ACTH}$, but not significantly at 1 and $100 \mathrm{ng} / \mathrm{m} l$. GABA at $0.1,10$ and $1000 \mathrm{ng} / \mathrm{m} l$ did not show any effect on the $\mathrm{HY}-\mathrm{CRF}$ induced release of ACTH. $\mathrm{PGE}_{1}$ and $\mathrm{PGE}_{2}$ at 1 and $10 \mathrm{ng} / \mathrm{m} l$ did not affect

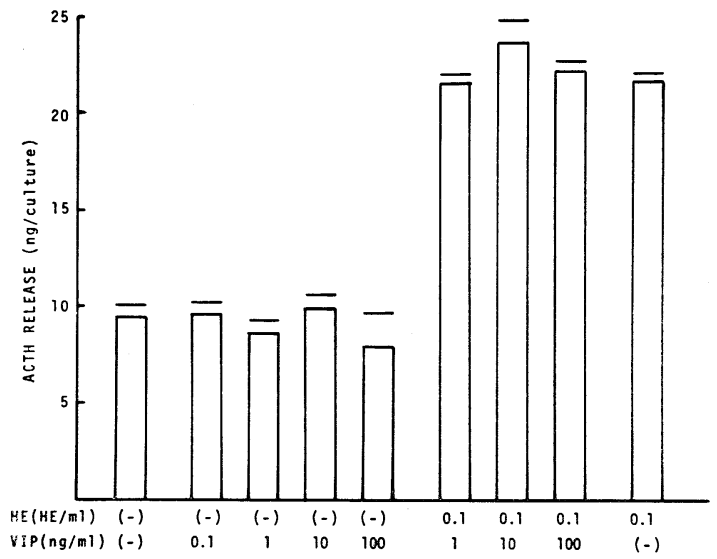

Fig. 4. Effect of VIP on the basal and $0.1 \mathrm{HE} / \mathrm{m} l$ induced release of ACTH in pituitary cell cultures.

Table 1. Effect of neurogenic peptides on HE induced release of ACTH in pituitary cell cultures.

\begin{tabular}{|c|c|c|c|c|c|}
\hline \multirow{2}{*}{\multicolumn{2}{|c|}{ Test substance $(\mathrm{ng} / \mathrm{m} l)$}} & \multicolumn{4}{|c|}{ ACTH Release (ng/culture) } \\
\hline & & \multirow{2}{*}{$\begin{array}{c}0 \\
3.92 \pm 0.80\end{array}$} & \multirow[t]{2}{*}{1} & \multirow[t]{2}{*}{10} & \multirow[t]{2}{*}{100} \\
\hline a) & Control & & & & \\
\hline & $\mathrm{HE}(0.1 \mathrm{HE} / \mathrm{m} l)$ & $13.07 \pm 1.30$ & & & \\
\hline & $\mathrm{HE}+\mathrm{TRH}$ & & $12.12 \pm 0.14$ & $12.87 \pm 1.37$ & $9.70 \pm 0.74$ \\
\hline & $\mathrm{HE}+$ Somatostatin & & $12.83 \pm 2.57$ & $14.67 \pm 1.09$ & $12.88 \pm 1.57$ \\
\hline \multirow[t]{5}{*}{ b) } & Control & $2.19 \pm 0.52$ & & & \\
\hline & $\mathrm{HE}(\bullet .1 \mathrm{HE} / \mathrm{m} l)$ & $6.49 \pm 0.41$ & & & \\
\hline & $\mathrm{HE}+\mathrm{LH}-\mathrm{RH}$ & & $5.47 \pm 0.10$ & $6.59 \pm 0.89$ & $6.20 \pm 0.76$ \\
\hline & $\mathrm{HE}+\beta$-endorphin & & $6.04 \pm 0.32$ & $6.01 \pm 0.39$ & $6.20 \pm 0.26$ \\
\hline & $\mathrm{HE}+$ Neurotensin & & $5.43 \pm 0.25$ & $5.74 \pm 0.14$ & $5.72 \pm 0.40$ \\
\hline \multirow[t]{4}{*}{ c) } & Control & $4.18 \pm 0.30$ & & & \\
\hline & $\mathrm{HE}(0.05 \mathrm{HE} / \mathrm{m} l)$ & $9.67 \pm 0.50$ & & & \\
\hline & $\mathrm{HE}+\mathrm{MSH}-\mathrm{IF}$ & & $8.47 \pm 0.23$ & $8.87 \pm 0.41$ & $8.43 \pm 0.56$ \\
\hline & HE + Leu-enkephalin & & $7.60 \pm 0.57 * *$ & $8.27 \pm 0.13^{*}$ & $7.98 \pm 0.23 *$ \\
\hline \multirow[t]{4}{*}{ d) } & Control & $3.95 \pm 0.39$ & & & \\
\hline & $\mathrm{HE}(0.1 \mathrm{HE} / \mathrm{ml})$ & $10.29 \pm 0.44$ & & & \\
\hline & $\mathrm{HE}+$ Angiotensin II & & $9.72 \pm 0.06$ & $10.35 \pm 0.61$ & $9.48 \pm 0.20$ \\
\hline & $\mathrm{HE}+$ Substance $\mathrm{P}$ & & $9.53 \pm 0.82$ & $8.93 \pm 0.29$ & $9.90 \pm 0.78$ \\
\hline
\end{tabular}

Results are given as mean \pm SEM. Statistical significance is expressed as $* \mathbf{P}<0.05, \quad * * \mathbf{P}<0.01 \quad v s$. the amount of ACTH released by HE only. 
Table 2. Effect of neurotransmitter substances on HE induced release of ACTH in pituitary cell cultures.

\begin{tabular}{|c|c|c|c|c|c|}
\hline \multirow{2}{*}{\multicolumn{2}{|c|}{ Test substance $(\mathrm{ng} / \mathrm{m} l)$}} & \multicolumn{4}{|c|}{ ACTH Release (ng/culture) } \\
\hline & & 0 & 1 & 10 & 100 \\
\hline \multirow[t]{6}{*}{ a) } & Control & $0.93 \pm 0.04$ & & & \\
\hline & $\mathrm{HE}(0.1 \mathrm{HE} / \mathrm{m} l)$ & $5.02 \pm 0.37$ & & & \\
\hline & $\mathrm{HE}+$ Norepinephrine & & $5.47 \pm 0.25$ & $5.45 \pm 0.90$ & $5.58 \pm 0.38$ \\
\hline & $\mathrm{HE}+$ Serotonin & & $4.65 \pm 0.40$ & $5.60 \pm 0.62$ & $4.68 \pm 0.42$ \\
\hline & $\mathrm{HE}+$ Acetylcholine & & $5.05 \pm 0.90$ & $5.20 \pm 0.32$ & $6.06 \pm 0.56$ \\
\hline & $\mathrm{HE}+$ Histamine & & $5.01 \pm 0.33$ & $4.63 \pm 0.62$ & $4.37 \pm 0.03$ \\
\hline \multirow[t]{3}{*}{ b) } & Control & $2.19 \pm 0.52$ & & & \\
\hline & $\mathrm{HE}(0.1 \mathrm{HE} / \mathrm{m} l)$ & $6.66 \pm 0.33$ & & & \\
\hline & HE+Dopamine & & $5.79 \pm 0.21$ & $4.95 \pm 0.25 *$ & $5.41 \pm 0.26$ \\
\hline \multirow{3}{*}{ c) } & Control & $2.04 \pm 0.84$ & & & \\
\hline & $\mathrm{HE}(0.1 \mathrm{HE} / \mathrm{m} l)$ & $4.94 \pm 0.14$ & & & \\
\hline & $\mathrm{HE}+\mathrm{GABA}$ & & a) $4.47 \pm 0.08$ & b) $4.89 \pm 0.84$ & c) $4.38 \pm 0.29$ \\
\hline \multirow[t]{4}{*}{ d) } & Control & $3.09 \pm 0.07$ & & & \\
\hline & $\mathrm{HE}(0.1 \mathrm{HE} / \mathrm{m} l)$ & $5.07 \pm 0.20$ & & & \\
\hline & $\mathrm{HE}+\mathrm{PGE}_{1}$ & & $5.37 \pm 0.29$ & $4.83 \pm 0.28$ & $4.13 \pm 0.21 *$ \\
\hline & $\mathrm{HE}+\mathrm{PGE}_{2}$ & & $5.06 \pm 0.22$ & $5.01 \pm 0.06$ & $4.04 \pm 0.16 *$ \\
\hline
\end{tabular}

Results are given as mean \pm SEM. Statistical significance is expressed as $* \mathrm{P}<0.05$ vs. the amount of ACTH released by HE only. Sign a), b) and c) represent the concentration of GABA at $0.1,10$ and $1,000 \mathrm{ng} / \mathrm{ml}$, respectively.

HY-CRF induced release of ACTH, but these substances $100 \mathrm{ng} / \mathrm{m} l$ suppressed the HY-CRF-induced release of ACTH.

\section{Discussion}

Hypothalamus contains many kinds of biologically active peptides and neurotransmitter substances. Among these substances, corticotropin releasing hormone is thought to be a specific and most potent ACTH releaser, although vasopressin and some other substances have been shown to have slight CRF-like activity (Fleisher and Vale, 1968; Chan et al., 1969; Hiroshige, 1971; Buckingham and Hodges, 1977). As genuine corticotropin releasing hormone is not yet available, hypothalamic extract was used as a hypothalamic CRF in the present investigation. Corticotropin releasing activity in crude $\mathrm{HE}$ can be ascribed to corticotropin releasing hormone, because 0.1 $\sim 0.2 \mathrm{HE}$ are not sufficiently contaminated with other substances to stimulate the release of $\mathrm{ACTH}$.
Yates et al. (1971) reported that the adrenocortical response to CRF was increased by the prior intravenous and intrapituitary administration of subthreshold doses of vasopressin. However, Portanova and Sayers (1973) observed using isolated pituitary cells that arginine vasopressin added in combination with appropriate doses of hypothalamic median eminence extract inhibited ACTH secretion. Yasuda and Greer (1976) also observed that vasopressin at 1 or $10 \mathrm{ng} / \mathrm{dish}$ rather suppressed the release of ACTH induced by $0.1 \mathrm{HE} / \mathrm{dish}$ in pituitary cell cultures, but that large doses of vasopressin showed neither stimulatory nor inhibitory effect on the HE-induced release of ACTH. Our present data show rather slightly additive effect of vasopressin on HY-CRF induced release of ACTH. The discrepancy among these results is difficult to explain by the present results.

In the present investigation, most of the tested substances did not show any significant effect on the HY-CRF induced release of ACTH. Somatostatin was reported to suppress not only $\mathrm{GH}$ secretion but other 
pituitary hormones (Murayama and Ishikawa, 1977). High doses of somatostatin also suppressed ACTH release. However, somatostatin nearer to the physiological level did not suppress the basal or HY-CRF induced release of ACTH in our pituitary cell cultures. The results suggest that somatostatin has no physiological effect on ACTH secretion. Substance $P$ and neurotensin which stimulated GH secretion in systemic administration (Kato et al., 1976; Rivier et al., 1977) did not show any effect on ACTH release at the pituitary level. It was expected that $\beta$-endorphin might affect the secretion of ACTH, as we had observed that $\mathrm{HE}$ stimulated $\beta$-endorphin release in pituitary cell cultures similar to ACTH release (Kageyama et al., 1978). But our previous and present data show that it has no effect on the secretion of ACTH at least at the pituitary level. Leu-enkephalin showed an inhibitory effect on HY-CRF-induced release of ACTH. But the inhibitory effect was not dose-related. Dopamine also suppressed the HY-CRF induced-released of ACTH, but the suppression was slight and not dose-related. Therefore, the suppressive effect of these substances might be not physiological.

Peng et al. (1970), and Hedge and Hanson (1972) indicated that $\mathrm{PGE}_{1}$ acted at some level in the central nervous system possibly at the hypothalamus to increase plasma corticosterone levels. Our data show that $\mathrm{PGE}_{1}$ and $\mathrm{PGE}_{2}$ reduced the release of ACTH induced by HY-CRF. The results confirms our previous finding (Takahara et al., 1977). Vale et al. (1971) once reported that $\mathrm{PGE}_{1}$ acted on the pituitary to release ACTH directly. However, Vale and Rivier (1977) reported recently that $\mathrm{PGE}_{1}$ suppressed the release of ACTH induced by HY-CRF. Norepinephrine and GABA were shown to suppress the serotonin or acetylcholine induced release of CRF from hypothalamic fragment (Jones et al., 1976). Histamine elevated plasma 17-OHCS when given in systemic administration (Suzuki et al., 1963). However, neither norepinephrine, GABA, serotonin nor histamine showed any effect on the HY-CRF induced release of ACTH in pituitary cell cultures. Therefore, the site of action of these substances can be ascribed to the central nervous system.

The present results suggest that pituitary ACTH secretion is controlled specifically by HY-CRF and corticosterone, and is slightly modified by other substances such as vasopressin and prostaglandins at the pituitary level. The effect of other neurogenic peptides or neurotransmitter substances seems to be negligible or non-physiological at least at the pituitary level.

\section{Acknowledgements}

The authors are grateful to Professor Noboru Yanaihara for the generous gifts of somatostatin and VIP.

\section{References}

Buckingham, J. C. and J. R. Hodges (1977). J. Endocr. 72, 187.

Chan, L. T., D. de Wied and M. Saffran (1969). Endocrinology 84, 967.

de Wied, D., A. Witter, D. H. G. Versteeg and A. H. Mulder (1969). ibid. 85, 561.

Fleisher, N. and W. Vale (1968). ibid. 83, 1232.

Hashimoto, K., J. Takahara, H. Hosogi, N. Ofuji, Y. Yasuhara, M. Mori and T. Ofuji (1976). Folia Endocrinol. Jap. 52, 114. (In Japanes:).

Hashimoto, K., S. Yunoki, H. Hosogi, J. Takahara and T. Ofuj1 (1978). Acta Medica Okayama (In press).

Hedge, G. A. and S. D. Hanson (1972). Endocrinology 91, 925.

Hiroshige, T. (1971). Med. J. Osaka Univ. 21, 161. Jones, M. T., E. W. Hillhouse and J. Burden (1976). J. Endocr. 69, 1.

Kageyama, J., N. Ogawa, K. Hashimoto, S. Yunoki, J. Takahara and T. Ofuji (1978). Igaku no Ayumi 107, 251 (In Japanese)

Kato, Y., K. Chihara, S. Ohgo, Y. Iwasaki, H. Abe and H. Imura (1976). Life Sci. 19, 441.

Murayama, T. and H. Ishikawa (1977). Biochem. Biophy. Res. Comm. 74, 1083. 
Peng. T. C., K. M. Six and P. L. Munson (1970). Endocrinology 86, 202.

Portanova, R. and G. Sayers (1973). Proc. Soc. Exp. Biol. Med. 143, 661.

Rivier, C., W. Vale, N. Ling, M. Brown and R. Guillemin (1977). Endocrinology 100, 238.

Suzuki, T., K. Hirai, H. Yoshio, K. Kurouji and K. Yamashita (1963). Am. J. Physiol., 204, 847.

Takahara, J., M. Mori, N. Ofuji, K. Hashimoto, J. Yamauchi, Y. Yamane, H. Hosogi and T. Ofuji
(1977). Endocrinol. Japon. 24, 97.

Vale, W. and C. Rivier (1977). Fed. Proc. 36, 2094.

Vale, W., C. Rivier and R. Guillemin (1971). ibid. $30,363$.

Vale, W., G. Grant, M. Amoss, R. Blackwell and R. Guillemin (1972). Endocrinology 91, 562.

Yasuda, N. and M. A. Greer (1976). ibid. 98, 936.

Yates, F. E., S. M. Russell, M. F. Dallman, G. A. Hedge, S. M. MacCann and A. P. S. Dhariwal (1971) ibid. 88, 3. 